\title{
THE IMAGE OF COMPANY, ESSENTIAL FACTOR IN DEVELOPING THE MARKET STRATEGIES
}

\author{
Lecturer PhD Student, Florin Radu Pintea, "Bogdan University" \\ of Cluj-Napoca, Romania, radupsr200@yahoo.com \\ Associate Professor PhD, Janetta Sîrbu “Bogdan University”of \\ Cluj-Napoca,Romania, sjanetta2002@yahoo.com \\ Professor PhD Boris Samochis, Bogdan Voda University, \\ Cluj-Napoca
}

\begin{abstract}
The project has been done in order to proove the importance of the image inside a large company. Thus I analysed the image of Electrolux company in order to show how important is the invisible part of a big company, regarding the market and the marketing strategies.

The questionnaire was made of 14 questions and there were 400 people who had to answer. During the research I used mathematics methods such as Fischbein and $\mathrm{Hi}^{2}$ method. The main purpose of a marketing research is the analyse of the numbers and factors, the essential keys that guide the company to a real marketing strategy. Analysing the dates there are some ideas that should be taken in consideration in order to build a stronger image of the company on the market, ideas that I detailed within the project.
\end{abstract}

Keywords: company, questionnaire, marketing strategies, marketing research

JEL Codes: M31

\section{Introduction}

„The act of buying” is greatly influenced by the psychological factor, a factor that starts on the premises that the processes of perception, the knowledge processes in general, vary between certain limits, generating different reactions from one individual to another. Given this particular context, the perception of the changes that take place in the environment occupy a very important place when it comes to taking a decision of buying or not a certain product. The area of perception of the individual comprises also the product and his objective characteristics: shape, colour, weight etc., giving birth to some feelings, and further on to some satisfactions, needs, and varied desires. The human mind can be thought of as the element that transforms the objective reality into a subjective „reality”, through the phenomenon of reflection into the person's knowledge (this knowledge process can be explained with the help of the image notion).

The image of the brand or of the product is built step by step, but once it is built it represents a key-element in the attitude of the consumer for the product. This is due to the fact that, generally, the consumer gets used to that specific brand and can remain faithful to it for a long time, or, on the contrary, he is permanently disapproving it (T.Prună). Despite this tendency of the increasing prices in time, and despite the inflation, the price/quality relationship remained basically the same. To this concern there are although some differences, at the level of the classes of products:

- in the case of long-term goods the price represents a quite precise quality-indicator;

- in the case of some other goods, this relationship is less intense, the information concerning the price having to be accompanied by other relevant information in the buying process (I. Cătoiu, N. Teodorescu, 2001, pag. 59-64). 
The image studies are founded on a series of specific indicators that reflect the fundamental coordinates of a brand's image on a certain market. In this sense, a complex research will take into consideration: the content, the intensity of the image, its formation and evolution processes as well as the precision and specificity of the image. The content of the image is mostly analysed from the point of view of the following alternative features: masculine-feminine; young-old; regularluxurious; distinguished- vulgar; dynamic - less dynamic; artificial- natural; strong-weak, etc. As far as the intensity of the image is concerned, the degree in which the image is encountered throughout different categories of consumers and the degree in which the specific features of that particular image are defined are studied. The more the image of the product is encountered, the bigger its degree of penetrating the market.

\section{Work method}

The paper includes a marketing study (based on a questionnaire) of the Electrolux România S.A. Satu Mare company image, a company integrated in the Electrolux Group. The famous brands AEG, Zanussi, Frigidaire, Eureka and Husquarna are part of the Electrolux Group also. The phase in which the objectives, the hypotheses and the variables of the research are established basically implies the explanation of the purpose of the research and of the foreseeable results. The overall purpose of the present marketing study is represented by the evaluation of one of the components, the dimension of the consumer's behaviour- the image towards the Electrolux România S.A. Satu Mare company. The following objectives are circumscribed to this overall purpose, objectives that consist in obtaining information concerning:

- the degree in which the consumers posses products of the Zanussi gas cookers brand, produced by Electrolux România S.A. Satu Mare

- the degree in which the Electrolux brand is individualized among other brands in the country, brands that produce long-term goods;

- the degree in which the Zanussi gas cookers brand is individualized among other gas cookers brands;

- the role of the main commercial characteristics in the formation and evolution of the image of the Zanussi gas cookers brand; image;

- the role of the commercial publicity in the formation and evolution of the Electrolux brand

- the place of the Electrolux brand as compared to the brands that produce similar consumer goods on our market;

- the reason for not consuming Electrolux products;

- the measures that have to be taken in order to improve the image of the Electrolux brand on the consumer goods market.

\section{The presentation of the questionnaire and of the sample used}

The questionnaire comprises the following variables:

- the degree of endowment with gas cookers;

- the importance given to the commercial characteristiques specific to a gas cooker, meaning price, design, number of burners, dimension, additional services;

- the degree in which the Zanussi gas cookers are appreciated for their design, price, number of burners, dimension, additional services;

- the degree in which the Zanussi gas cookers are appreciated as compared to other similar brands on the Romanian market, such as: Metalica, Ardo, Meister, Bosch, Indesit 
- the degree in which the Electrolux brand products are appreciated as compared to other similar brands that produce long-term consumer goods on the Romanian market

- the degree in which the commercial advertising for the Zanussi gas cookers is appreciated

- the most appropriate way for advertising

- the measures that have to be taken in order to improve the image of the brand

- the subjects' lifestyle

- the subjects' occupation

- the subjects' income

The sampling method has been used for the examined community, a method that „starts from the idea that the sample often allows a higher global level of accuracy than a full enumeration" (C.A Moser, 1967, pag. 81). The theoretical size of the sample was established by using the following association:

$$
n=\frac{t^{2} \cdot p \cdot(1-p)}{\Delta w^{2}}
$$

where: $\mathrm{n}=$ the size of the sample;

$\mathrm{t}=$ the coefficient that corresponds to the prabability which guarantees the results

$\mathrm{p}=$ the proportion of the sample's elements that posses the examined characteristic

$\Delta \mathrm{w}=$ the limited error accepted

Carrying out this association for a probability of guaranteeing the results of $95,5 \%(t=2)$, for a $p$ that takes the value of 0,5 because it is unknown and for an accepted limited error of $\pm 5 \%$ we obtain:

$$
n=\frac{2^{2} \cdot 0,5 \cdot(1-0,5)}{0,05^{2}}=400
$$

For the sample to be representative, it has to be conceived, in the present case, according to the aleatory selection method, a method that allows to each of the units comprised into the general community the same countable probability, other than 0 , of being chosen for the sample. The observation unity is one and the same with the inquiry unity and it reffers to the individual that visits the stores that commercialize long-term consumer goods. In order to suit these demands, the following types of questions have been used in the questionnaire:

- $\quad$ fixed questions : 1,2,7-14;

- factual data questions: 1,2, 12-14;

- opinion questions: 4-10;

- identification questions: 12-14.

The practice generally demands for the inquiry to be precedeed by a pilot-inquiry. Its role is that of obtaining a feed-back that provides useful information for improving the questionnaire. Some questions that seem very simple and clear to the person that made the questionnaire could turn out to be very difficult and confused for the person to be investigated. Only by submitting them to a test this issue can be discovered and the necessary modifications can be made. During this phase the possibility for the realization of a general repetition appears, offering at the same time answers to some other organizational issues of the poll such as the verification of the methods through which the information has been collected, the optimum time for inquiring the subjects. The pilot-inquiry took place between 9-15 December 2007 inside the Quatro store and consisted in inquiring 50 subjects. The following aspects have been underlined:

- the questionnaire corresponds content wise; 
- as far as the shape is concerned, there have been some questions that needed to be more clearly reformulated: 3 and 8 ;

- the optimum time for inquiry is of 15 minutes with a break between the interviews of 5 minutes.

Because during the pilot-inquiry the only difficulties have been normal, needing some additional explanations, the answers that were obtained have been valided, those subjects being included in the sample. The image study of the Electrolux brand has practically taken place between 11-20 march 2008 at the following stores: Altex, Focus, Quatro and the specialized department of the universal store Someşul. In choosing these commercial units the starting point consisted in the appreciation that the territorial criterion is not significant, the information about the Electrolux brand not being influenced by the placing of the residence in a zone or another of the city.

In establishing the structure of the sample, a series of criteria has been taken into consideration, criteria that were used for drawing up the identification questions of the sample, such as: the occupation, the age and the subjects' income. These criteria greatly influence the formation of the Electrolux România S.A. Satu Mare brand image throughout the examined persons. Therefore, according to the occupation criterium, the structure of the sample looks as it follows (Table no.1):

Table no.1

The structure according to the profession criterium

\begin{tabular}{|l|l|r|r|}
\hline Crt. No. & Occupation & Absolute value & Structure (\%) \\
\hline 1. & Employees & 272 & 68,0 \\
\hline 2. & Employers & 24 & 6,0 \\
\hline 3. & Retired persons & 52 & 13,0 \\
\hline 4. & Unemployed persons & 21 & 5,25 \\
\hline 5. & Agricultors & 31 & 7,75 \\
\hline 6. & TOTAL & 400 & 100,0 \\
\hline
\end{tabular}

As far as the age of the examined subjects is concerned, it can be observed that the sample is in majority composed by persons that fit the 21-40 years age category, that is to say a proportion of $48 \%$. By including also those persons with less than 20 years, it can be concluded that those that visit the stores that commercialize long-term goods are relatively young persons (Table no. 2). The interest for long-term goods is more reduced throughout old people, be it because they already have this type of goods in their homes, be it because their incomes as retired persons will not allow them to buy such goods.

Table no. 2

The structure according to the age categories

\begin{tabular}{|l|l|r|r|}
\hline $\begin{array}{l}\text { Crt. } \\
\text { No. }\end{array}$ & Age & Absolute value & Structure (\%) \\
\hline 1 & Less than 20 years & 60 & 15 \\
\hline 2 & Between 21-40 years & 192 & 48 \\
\hline 3 & Between 41-60 years & 116 & 29 \\
\hline 4 & Over 60 years & 32 & 8 \\
\hline 5 & TOTAL & 400 & 100 \\
\hline
\end{tabular}

Within the sample, according to the income criterium, it can be observed that most of the subjects fit within the 300-600 lei group of income. The group of income within the limit of 300 lei is represented in a proportion of over $29 \%$, and the subjects with incomes of over 600 lei in a proportion of $20 \%$, fact that corresponds to the structure at the level of the entire community (Table no. 3). 
Table no.3

The structure according to the income criterium

\begin{tabular}{|l|l|r|r|}
\hline Crt. No. & Group of income & Absolute value & Structure (\%) \\
\hline 1. & Less than 300 lei & 118 & 29,5 \\
\hline 2. & $300-600$ & 202 & 50,5 \\
\hline 3. & Over 600 & 80 & 20,0 \\
\hline 4. & TOTAL & 400 & 100,0 \\
\hline
\end{tabular}

\section{Outcomes}

All the subjects that have been inquired posses a gas cooker. Throughout the examined subjects, over $81 \%$ posses Zanussi gas cookers (Electrolux) (Table no.4).

Table no.4

The degree in which the Zanussi (Electrolux) gas cookers can be encountered

\begin{tabular}{|l|l|r|r|}
\hline Crt. No. & Group of products & Absolute value & \multicolumn{2}{|c|}{ Structure (\%) } \\
\hline 1. & Zanussi brand & 326 & 81,5 \\
\hline 2. & Other brand & 74 & 18,5 \\
\hline 3. & TOTAL & 400 & 100,0 \\
\hline
\end{tabular}

Table no. 4 confirms the hypothesis according to which the majority of subjects that posses gas cookers of the Electrolux România S.A. Satu Mare brand. These values demonstrate a high degree of penetration of the market of the gas cookers produced by the studied brand. Only 18,5\% of the examined subjects posses gas cookers produced by some other brand, fact that demonstrates that the products belonging to the Electrolux România S.A. Satu Mare brand is very well-defined throughout the consumers. It is interesting to see if this characteristic - the degree in which the Zanussi gas cookers is encountered- is influenced by the occupation, age or income of the examined persons.

In order to verify the null hypotheses in each case, the $\chi^{2}$ test previously presented is used. In the case of the verification of the influence of the subjects' occupation over the degree in which the Zanussi brand gas cookers can be encountered, the following table of contingency is drawn up (Table no. 5):

Table no.5

The distribution of the degree of possession according to the subjects' occupation

\begin{tabular}{|l|r|r|r|r|r|r|}
\hline $\begin{array}{l}\text { occupation } \\
\text { possession }\end{array}$ & Employees & $\begin{array}{l}\text { Emplo } \\
\text { yers }\end{array}$ & $\begin{array}{l}\text { Retired } \\
\text { persons }\end{array}$ & \multicolumn{1}{|l}{$\begin{array}{l}\text { Unemployed } \\
\text { persons }\end{array}$} & agricultors & TOTAL \\
\hline owners & $225_{(222)}$ & $22_{(20)}$ & $40_{(42)}$ & $16_{(17)}$ & $23_{(25)}$ & 326 \\
\hline $\begin{array}{l}\text { Persons } \\
\text { that do not } \\
\text { posses }\end{array}$ & $47_{(50)}$ & $2(4)$ & $12_{(10)}$ & $55_{(4)}$ & $8_{(8)}$ & 74 \\
\hline TOTAL & 272 & 24 & 52 & 21 & 31 & 400 \\
\hline
\end{tabular}

$\chi_{\text {calc. }}^{2}=2,384$ The theoretical value that corresponds to $(2-1)(5-1)=4$ degrees of freedom and a level of importance of 0,05 (that means a $95 \%$ probability) is $\chi^{2}=9,488$. As $\chi_{\text {calc. }}^{2} \chi_{\text {theoretical, this means }}^{2}$ that the null hypothesis is accepted, meaning that the degree of possession of the Zanussi brand gas cookers is not influenced by the subjects' occupation. The contingency table for the case in which the age is taken into consideration is at follows (Table no.6): 
Table no. 6

The distribution of the possession degree on age groups

\begin{tabular}{|c|c|c|c|c|c|}
\hline $\begin{array}{c}\text { age } \\
\text { Possession }\end{array}$ & $\begin{array}{l}\text { Less than } 20 \\
\text { years }\end{array}$ & $\begin{array}{l}21-40 \\
\text { years }\end{array}$ & $\begin{array}{l}41-60 \\
\text { years }\end{array}$ & $\begin{array}{ll}\text { over } & 60 \\
\text { years } & \end{array}$ & TOTAL \\
\hline owners & $51_{(49)}$ & $158_{(156)}$ & $93_{(95)}$ & $24_{(26)}$ & 326 \\
\hline $\begin{array}{l}\text { Persons } \\
\text { that do not } \\
\text { posses }\end{array}$ & $9_{(11)}$ & $34_{(36)}$ & $23_{(21)}$ & $8_{(6)}$ & 74 \\
\hline TOTAL & 60 & 192 & 116 & 32 & 400 \\
\hline
\end{tabular}

$\chi_{\text {calc. }}^{2}=1,635$ The theoretical value that corresponds to $(2-1)(4-1)=3$ degrees of freedom and a level of importance of 0,05 is $\chi^{2}=7,815$. As $\chi_{\text {calc. }}^{2}<\chi_{\text {theoretical, }}^{2}$ it means that for a $95 \%$ probability the null hypothsis is accepted, meaning that the degree of possesion of the Zanussi brand gas cookers is not influenced by age.

In order to test the income's influence over the degree of possesion we have as a starting point the table below:

Table no. 7

The distribution of the possesion degree on income groups

\begin{tabular}{|l|r|r|r|r|}
\hline \multicolumn{1}{|c|}{ Incomes } & Less than 300 lei & $\begin{array}{l}\text { Between } \\
\text { 300-600 lei }\end{array}$ & $\begin{array}{l}\text { More } \\
\text { than 600 lei }\end{array}$ & TOTAL \\
Possesion & $101_{(96)}$ & $162_{(165)}$ & $63_{(65)}$ & 326 \\
\hline Owners & $17_{(22)}$ & $40_{(37)}$ & $17_{(15)}$ & 74 \\
\hline $\begin{array}{l}\text { Persons that do } \\
\text { not posses }\end{array}$ & 118 & 202 & 80 & 400 \\
\hline TOTAL & & & & \\
\hline
\end{tabular}

$\chi_{\text {calc. }}^{2}=2,022$ The theoretical value that corresponds to (2-1)(3-1)=2 degrees of freedom and a level of importance of 0,05 is $\chi^{2}=5,991$. As $\chi_{\text {calc. }}^{2} \chi_{\text {theoretical, }}^{2}$ it means that for a $95 \%$ probability the null hypothsis is accepted, meaning that the degree of possesion of the Zanussi brand gas cookers is not influenced by the subjects' income. As a consequence of these outcomes, it means that despite the occupation, age or income of the subjects, the majority of the examined persons posses a gas cooker produced by Electrolux România S.A. Satu Mare in their homes. This is also due to the fact that the studied company has the biggest weight on the market as compared to the other companies that produce gas cookers in our country or from the import activities.

In order to extend the analysis concerning the image of the studied brand, the degree of fame of the brand has to be analyzed, as well as the degree in which its image is individualized among other brands that produce long-term goods in our country: Indesit, Samsung, Sony, Arctic, LG. As a consequence of the link made between the products and their brands, the examined persons have been separated in 2 groups (Table no. 8):

- group I - those that recognized the Electrolux company as a gas cooker producer;

- group II - those that didn't recognize the Electrolux company as a gas cooker producer. 
Table no. 8

The degree in which the Electrolux brand is known on the market

\begin{tabular}{|l|l|r|r|}
\hline Crt. No. & Group & Absolute value & Structure (\%) \\
\hline 1. & I & 362 & 90,5 \\
\hline 2. & II & 38 & 9,5 \\
\hline 3. & TOTAL & 400 & 100,0 \\
\hline
\end{tabular}

$90,5 \%$ of the persons examined have managed to identify the Electrolux brand as a producer of gas cookers. The anonymity of the company as a gas cooker producer, in a reduced proportion, of only $9,5 \%$ is due to the fact that in time the company bore several other denominations: „1 September”, „23 August”, „Samus”, „Samus-Electrolux” and „Electrolux”. It is again the issue of whether the occupation or the age of the subjects have any influence upon the degree in which the Electrolux brand has been individualized among the other companies presented. In order to verify the influence of the occupation, the contingency table below in drawn up (Table no. 9):

Table no. 9

The distribution of the degree of fame of the Electrolux brand on occupations

\begin{tabular}{|l|r|r|r|r|r|r|}
\hline $\begin{array}{l}\text { occupation } \\
\text { group }\end{array}$ & employees & employers & $\begin{array}{l}\text { Retired } \\
\text { persons }\end{array}$ & $\begin{array}{l}\text { Unemploy } \\
\text { ed persons }\end{array}$ & agricultors & TOTAL \\
\hline I & $266_{(246)}$ & $24_{(22)}$ & $40_{(47)}$ & $18_{(19)}$ & $14_{(28)}$ & 362 \\
\hline II & $6_{(26)}$ & $0_{(2)}$ & $12_{(5)}$ & $3_{(2)}$ & $17_{(3)}$ & 38 \\
\hline $\begin{array}{l}\text { TOTA } \\
\text { L }\end{array}$ & 272 & 24 & 52 & 21 & 31 & 400 \\
\hline
\end{tabular}

$\chi_{\text {calc. }}^{2}=100,92$ The theoretical value that corresponds to $(2-1)(5-1)=4$ degrees of freedom and a level of importance of 0,05 (meaning a probability of $95 \%$ ) is $\chi^{2}=9,488$. As $\chi_{\text {calc. }}^{2} \chi_{\text {theoretical, }}^{2}$ this means that for a probability of $95 \%$ the null hypothesis is rejected. Therefore, the fame degree of the Electrolux brand is influenced by the occupation of the examined persons. It has been observed that the majority of those that didn't recognize the Electrolux brand as producer of gas cookers is formed by agricultors and retired persons, especially because of the new denomination of the producing company (Table no.10).

Table no. 10

The distribution of the fame degree of the Electrolux brand on age groups

\begin{tabular}{|l|r|r|r|r|r|}
\hline \multicolumn{1}{|c|}{ age } & \multicolumn{1}{l}{$\begin{array}{l}\text { Less than 20 } \\
\text { years }\end{array}$} & $\begin{array}{l}\text { ll-40 } \\
\text { years }\end{array}$ & $\begin{array}{l}\text { l1-60 } \\
\text { years }\end{array}$ & \multicolumn{1}{l|}{$\begin{array}{l}\text { yver } \\
\text { years }\end{array}$} & TOTAL \\
\hline owners & $55_{(54)}$ & $175_{(174)}$ & $102_{(105)}$ & $30_{(29)}$ & 362 \\
\hline $\begin{array}{l}\text { Persons } \\
\text { that do not } \\
\text { posses }\end{array}$ & $5_{(6)}$ & $17_{(18)}$ & $14_{(11)}$ & 2 & 38 \\
\hline TOTAL & & & & & \\
\hline
\end{tabular}

$\chi_{\text {calc. }}^{2}=1,518$ The theoretical value that corresponds to $(2-1)(4-1)=3$ degrees of freedom and a level of importance of 0,05 is $\chi^{2}=7,815$. Therefore, for a probability of $95 \%$ the null hypothesis is accepted because $\chi_{\text {calc. }}^{2}<\chi^{2}$ theoretical. It means that the fame degree of the Electrolux brand is not influenced by the subjects' age.

It is compulsory then to know the interdependence between the precision of the image and the degree of possesion of the gas cookers produced by Electrolux România S.A. Satu Mare. In order to be able to study this issue, the $\chi^{2}$ test is used again along with the following table of contingency (Table no.11): 
Table no. 11

The distribution of the fame degree of the

Electrolux brand according to the possesion criterium

\begin{tabular}{|l|r|l|r|}
\hline Group & Owsesion & $\begin{array}{l}\text { Persons that do not } \\
\text { posses }\end{array}$ & TOTAL \\
\hline I & $291_{(295)}$ & $71_{(67)}$ & 362 \\
\hline II & $35_{(31)}$ & $3_{(7)}$ & 38 \\
\hline TOTAL & 326 & 74 & 400 \\
\hline
\end{tabular}

$\chi_{\text {calc. }}^{2}=3,094$ The theoretical value that corresponds to $(2-1)(2-1)=1$ degrees of freedom and a level of importance of 0,05 is $\chi^{2}=3,841$. As $\chi_{\text {calc. }}^{2} \chi_{\text {theoretical }}^{2}$ the null hypothesis is accepted. Therefore, the fame degree of the Electrolux brand does not depend on the possesion of products of this brand, the image of the Electrolux România S.A. Satu Mare company being quite clearly shaped among the examined persons.

\section{Conclusions}

The marketing study that has been done offers the image of a company that managed to strengthen its position on the market through its products. On the market of long-term goods the Electrolux company is recognised as a producer of gas cookers, washing machines, freezers, kitchen chimney hoods, radiators etc. The Electrolux brand products are generally considered as superior from the qualitative point of view as compared to the other brands' products. The Electrolux România S.A. Satu Mare company takes advantage in the fact that its image is wellknown on the Romanian market and in the fact that a big part of its production is exported and neglects this very important aspect of advertising. The lack of an advertising department leads towards an unsuitable distribution of the catalogue of products or brochures. In order to improve the activity concerning the imposing of a better image of the Electrolux brand the following aspects can be proposed: the improving of the gas cookers price, because in the economical context of transition of our country the prices greatly influence the buying decision; the establishing of a department that has as a role the distribution of brochures and catalogue of products in all the stores that commercialize long-term goods, and the distribution towards the press, radio and TV of more commercial advertising.

Some other improvements concerning the image of the Electrolux brand reffers to the reorganization of the management and organisation system: the defining and focus on the objectives; a new organisational structure according to the functions and objectives of the company; the budget planning of all the activities; the permanent efficientization of the financial management; the control and analysis of the costs; the orientation towards customer satisfaction; the decentralization of the decision making process; the utilization of the informatical system; the integration into the group's system of indicators and relations.

In the relation system with the socio-economical environment or with the market, the marketing efforts of a modern company cannot be limited only to the production and distribution of goods and services. They imply a permanent and complex communication with the environment, with the market, a fact that consists in an attentive documentation on the possible consumers and on the agents, specific actions of influencing the buying and consumption behaviour and supporting the selling process. There is the conviction that by putting the presented proposals into practice, even if partially, the Electrolux România S.A. Satu Mare company will manage to better strengthen its image on the Romanian market. 


\section{References:}

1. Baker M. - Marketing, Ed. Societatea se Ştiință şi Tehnică, Bucureşti, 1997.

2. Cătoiu, I. Teodorescu N. - Comportamentul consumatorului, abordare instrumentală, Ed. Uranus, Bucureşti, 2001.

3. Demetrescu M. C. - Marketing, ediţia a 3-a, Ed. Fundația Europeană Drăgan, Bucureşti, 1991.

4. Dima C., Nedelcu Monica Viorica - Management industrial, Ed. Naţional, Bucureşti, 2000.

5. Dubois P.L. - Marketing, vol. 2, Ed. Ardealul, Cluj-Napoca, 1989.

6. Florescu C., coordonator - Marketing, Ed. Marketer, București, 1992.

7. Frone F. D. - Dicționar de marketing, Ed. Oscar Print, Bucureşti, 1999.

8. Kotler Ph. - Managementul marketingului, ed. a 2-a, Ed. Teora, București, 1996.

9. Lazăr D. - Cercetări de marketing, Ed. Universității din Oradea, Oradea, 2003.

10. Moser C.A. - Metode de anchetă in investigarea fenomenelor sociale, Ed. Ştiinţifică, Bucureşti, 1967.

11. Munteanu V. - Marketing - concepte, metode, studii de caz, vol. 1-2, Ed. Fundației Chemarea, Iaşi, 1996.

12. Păcurariu Gh. - Bazele Marketingului, Ed. Mirton, Timişoara, 2000.

13. Prună T. - Psihologie economică, Ed. Didactică şi Pedagogică, Bucureşti, 1976. 